\title{
K DOTVÁŘENÍ PRÁVA CESTOU ANALOGIE ANEB JAK ZVÝŠIT LEGITIMITU A PROSYSTÉMOVOST ANALOGICKÉ ARGUMENTACE V PRÁVU*
}

\author{
KATARZYNA ŽÁK KRZYŽANKOVÁ
}

\begin{abstract}
On the Filling of Statutory Gaps Using Analogy, or How to Increase the Legitimacy and Pro-systemicity of Analogical Argumentation in Law

The article presents the current state of knowledge regarding the use of analogy in domestic jurisprudence, with the aim of outlining its place and role in the process of finding the law. The performed analysis makes it possible to identify two main functions that the analogy performs, namely the heuristic function and, under certain circumstances, the legitimization function. If the analogy is to constitute a legitimate and retrospectively verifiable instrument of filling statutory gaps, the reasoning behind its use in a case under consideration must be presented in a logical form, which means the premises lying behind the argumentation by analogy must be reconstructed. Therefore, a deciding authority should, in particular, deal with a question of why the given case was a so-called analogous situation in law, justify the choice of the source of analogy (a particular legally regulated case or legal principle), and the way to resolve discrepancies between the case under consideration and the analogous one. The article concludes with an overview of the main problems that deciding authorities should pay attention to in situations where they fill statutory gaps using analogy, in which case their resolutions can be expected to increase the pro-systemic approach to law in the processes of law finding.
\end{abstract}

Keywords: analogy; analogical reasoning; similarity; pro-systemic approach

Klíčová slova: analogie; analogické usuzování; podobnost; prosystémovost

DOI: $10.14712 / 23366478.2021 .3$

\footnotetext{
* Tento př́spěvek vznikl v rámci plnění projektu Grantové agentury ČR reg. č. 19-10723S Co současné právo sjednocuje a co jej fragmentarizuje z pohledu současné právní teorie a soudní praxe?.
} 


\section{1. ÚVODEM ANEB K AKTUÁLNÍMU STAVU POZNÁNÍ O ANALOGII V TUZEMSKÉ PRÁVNÍ VĚDĚ}

\section{Problematika analogie patří $\mathrm{k}$ tradičním tématům ${ }^{1}$ nejenom právní vědy. ${ }^{2}$}

V posledních dvou dekádách lze přitom $\mathrm{v}$ českém i slovenském právním prostředí pozorovat zvýšený zájem o toto téma, jenž vyústil v částečné přehodnocení role a místa, jakou analogie plní v procesech nalézání práva.

Přesněji řečeno, významnost a přesvědčivost argumentace per analogiam a takto získaných závěrů - obdobně jako závěrů získaných při použití dalších tzv. zvláštních argumentů právní logiky - bývá relativizována. Je zejména ukazováno, že v pozadí těchto argumentů nestojí čistě formálně-logické operace, ${ }^{3}$ nýbrž je to úvaha interpreta, autorita soudů (resp. orgánů veřejné moci) či tradice, které určují, kdy bude aplikován ten který argument. ${ }^{4}$

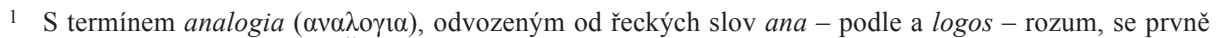
setkáváme ve starověkém Řecku u Epikurovců, kdy označoval srovnávání vztahů či proporcí, tj. vyja-

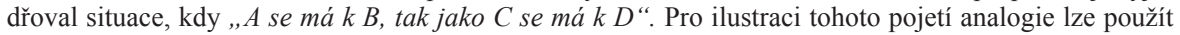
známý Aristotelův př́ílad ze Zoologie, dle kterého ,pera k ptákům se mají jako šupiny k hadům “. Je však třeba zdůraznit, že pro to, co dnes označujeme jako analogické usuzování, resp. analogické argumentace, používali Řekové zcela jiný termín. Jmenovitě homoiotes neboli argument z podobnosti, jehož podstatu Aristoteles v Topikách vysvětluje následovně: , ,ptej se oponenta na podobnosti, nebot' je to víc hodnověrné a obecný závěr je víc ukrytý. Např́klad, jestli věděni i nevěděni o protikladech je stejné, tak samotné zjištěni protikladů je stejné; anebo opačné, jestliže pozorování je stejné, tak i věděni (znalosti) je stejné. Tento argument je podobný indukci, ale není totožný; nebot' při indukci se celek získává z jednotlivých faktů, kdežto u přikladu z podobnosti, to, co ziskáváme, není obecný závěr, pod který by spadaly všechny podobné skutečnosti “(ARYSTOTELES. Topiki. 156b 10-17. In: ARYSTOTELES. Hermeneutyka: topiki: o dowodach sofistycznych. Warszawa: Państwowe Wydawnictwo Naukowe, 2013, s. 159). K etymologii slova analogia srov. HAAPARANTA, L. The Analogy Theory of Thinking. Dialectica. 1992, Vol. 46, No. 2, s. 171. K sémantickému uchopení analogie v antice a zajímavé středověké terminologické „rošádě“ pak srov. HOCHSCHILD, J. P. The Semantics of Analogy: Rereading Cajetan's 'De Nominum Analogia'. Notre Dame: Notre Dame University Press, 2010, s. 4 a násl.

2 Neznamená to však, že různé vědní obory pojímají analogii identicky. Jednotlivá vymezení sice vždy zmiňují v souvislosti s analogií „podobnost“", ,obdobu“, „,shodu“ či „,částečnou shodu“, tj. vykazují určité společné znaky, které reflektují obvyklé - z přirozeného jazyka pramenící intuice (analytická část pojetí), nicméně odráží i kontextová specifika př́slušných vědních oborů, kdy intuitivní význam bývá zúžen či dílem modifikován (syntetická, resp. normativní rovina pojetí). V některých oborech tak analogie slouží k pojmenování existujících mechanismů či fenoménů (biologie, jazykověda), jindy k vytváření nových hypotéz či teorií na základě (tvrzené či domnělé) podobnosti. Jak upozorňuje J. D. Norton, ve společenských vědách je přitom analogie obvykle pojímána jako způsob či forma usuzování, kdežto v prírodních vědách je analogie chápána jako „faktická“ záležitost, jejiž existenci lze zpětně empiricky ověřovat či zkoumat, a může být spojena s různými druhy (formami) úsudků (dedukci nevyjímaje). Srov. NORTON, J. D. Analogy. In: NORTON, J. D. The Material Theory of Induction. Philosophy of Science [online]. 2003, Vol. 70, No. 4 [cit. 2020-05-05]. Dostupné na: https://philpapers.org/rec/NORAMT. V této stati bude pozornost primárně věnována analogii v právu.

3 V tuzemském právním prostředí jako jeden z prvních proti (formálně)-logickému charakteru těchto operací vystoupil J. Čapek, jenž proto považoval za př́hodnější hovořit o ,zvláštnich postupech právního myšlení v procesech interpretace “ [ČAPEK, J. Interpretace socialistického práva (základní teoretické otázky). Acta Universitatis Carolinae Iuridica. 1983, Monographia XL, s. 47]. Expresivněji se proti specifické právní logice, potažmo tedy i tzv. zvláštním argumentům této logiky, o dvě dekády později vyslovil $\mathrm{F}$. Cvrček, který mj. dovozuje ,, absurdnost “ těchto termínů a vyzývá k opuštění ,,mýtu() o logické podstatě ... těchto argumentů “ (CVRĆEK, F. Kritické poznámky k výuce interpretace právních textů. In: GERLOCH, A. MARŠÁLEK, P. (eds.). Problémy interpretace a argumentace $v$ soudobé právní teorii a právní praxi. Praha: EurolexBohemia, 2003, s. 53). Na něj pak navázali L. Hlouch, F. Melzer, T. Sobek či J. Wintr.

4 CVRČEK, c. d., s. 53. 
Z téhož důvodu je za problematické stále častěji vnímáno i rozlišování tzv. logické metody výkladu, do jejíhož instrumentaria by analogie měla patřit, ${ }^{5}$ natož její řazení k základním či k tzv. standardním metodám výkladu, které by měl exeget přednostně využívat v rámci interpretačních procesů. ${ }^{6}$ Jde spíše - jak je upozorňováno - o součást teleologické metody výkladu, ${ }^{7}$ popř. způsob dotváření práva. ${ }^{8}$

V kontinentální právní vědě o analogii sensu stricto ${ }^{9}$ totiž obvykle hovoříme v situacích, kdy projednávaný právní prrípad nelze úspěšně podřadit pod žádnou zákonnou hypotézu, tj. kdy máme co do činění s mezerou (lacuna) - zejména pravou, nevědomou a počáteční - v zákoně. ${ }^{10}$ Zaznívají sice názory, že o analogii, a to konkrétně intra legem, lze hovořit i v př́padech, kdy normotvưrce v hypotéze určitého ustanovení výslovně vybízí k užití normy i na „obdobné“ prrípady, ${ }^{11}$ nicméně je nasnadě, že v těchto

5 Srov. například závěry J. Wintra, opřené o komparaci zahraničních přístupů, ale i recentní pohledy dalších představitelů české doktríny, které jej vedly k zamítnutí vyčleňování tzv. logické metody výkladu in: WINTR, J. Metody a zásady interpretace práva. 2. vyd. Praha: Auditorium, 2019, s. 19 a nás1. Na druhou stranu i přes tuto kritiku některé reprezentativní učebnice teorie práva z nedávné doby i nadále zmiňují logickou metodu výkladu, a v rámci ní pojednávají o tzv. zvláštních argumentech právní logiky, byt' neopomíjejí upozornit na problematičnost tohoto př́stupu (srov. PROCHÁZKA, R. - KÁČER, M. Teória práva. 2. vyd. Bratislava: C. H. Beck, 2019, s. 244).

6 K těm stále analogii, a přesněji argument per analogiam legis, řadí základní učebnicová pomůcka používaná na pražské právnické fakultě, tedy publikace: GERLOCH, A. Teorie práva. 7. vyd. Plzeň: Vydavatelství a nakladatelství A. Čeněk, 2017, s. 146. Analogie iuris je však tímto autorem řazena k teleologické metodě výkladu (tamtéž).

7 Činí tak např́klad: WINTR, Metody a zásady interpretace práva, s. 27 et passim. Ne všechny tzv. zvláštní argumenty však řadí k teleologické metodě výkladu. Argumentům a contrario a per eliminationem připadlo v jeho metodologii místo v rámci systematického výkladu, byt' je upozorňováno, že „,pro konečné rozhodnutí, zda argument a contrario má být použit, jsou podstatné teleologické úvahy" (s. 114).

8 Srov. kupŕíkladu MELZER, F. Metodologie nalézání práva: úvod do právní argumentace. 2. vyd. Praha: C. H. Beck, 2011, s. 243 a násl. et passim. Melzer ale rozlišuje mezi analogií (legis) a argumentací a simili, kdy s analogií máme co do činění v rámci dotváření práva při zaplňování otevřených mezer v zákoně, kdežto argumentum a simili je součástí interpretačních procesů a primárně slouží k výběru takové interpretační varianty, která nenarušuje hodnotovou koherenci právního řádu. Rovněž H. Schlosser pojímá analogii jako ,, metodu a prostredek vyplňování mezer v právu“ (VEČĚ̌A, M. - GERLOCH, A. - SCHLOSSER, H. - BERAN, K. - RUDENKO, S. Teória práva. 5. rozš. a dopl. vyd. Bratislava: EUROKÓDEX, 2013, s. 204), kdy již nelze hovořit o výkladu, ale dotváření práva. Analogii však bez dalšího spojuje s argumentem a simili, a pari (tamtéž).

9 Recentně je stále častěji upozorňováno, že analogické myšlení a usuzování plní v procesech (nejenom právního) poznávání a komunikace mnohem fundamentálnější roli, než se mu tradičně přisuzuje. $Z$ tuzemských autorů na tento fenomén jako jeden z prvních upozornil T. Sobek in: SOBEK, T. Právní myšlení: kritika moralismu. Praha: Ústav státu a práva, 2011, s. 185; v nedávné době pak - jak sám píše - o ,obhajobu analogie" - usiluje M. Káčer, a to zejména ve své monografii Na okraji krajnej núdze: o prepisovaní zákonov počas ich aplikácie. Tomuto pohledu na analogii však nebude v rámci tohoto příspěvku věnována větši pozornost. K analogii sensu largo proto srov. WINTER, S. L. A Clearing in the Forest: Law, Life and Mind. Chicago - London: The University of Chicago Press, 2001, s. 223-258; či WOJTCZAK, S. The Metaphorical Engine of Legal Reasoning and Legal Interpretation. Warszawa: C. H. Beck, 2017, s. 113 a násl.

10 Z bohaté literatury k mezerám v právu srov. HLOUCH, L. Teorie mezer a současné právní myšlení. Časopis pro právni vědu a právní praxi. 2013, č. 2, s. 129-136; VEČEŘA, M. Soudcovské dotváření práva. In: GERLOCH, A. - TRYZNA, J. - WINTR, J. (eds.). Metodologie interpretace práva a právní jistota. Plzeň: Vydavatelství a nakladatelství A. Čeněk, 2012, s. 227-232 či třeba WINTR, Metody a zásady interpretace práva, s. 109 a násl.

11 Typicky u demonstrativních výčtů, kdy se používají výrazy jako „zejména“, „například“, ,,a podobně“, a tedy kdy normotvưrce jasně dává najevo, že rozsah právní normy je širší než v textu explicitně vyjádřené vzorové příklady. Obdobně lze ale pojímat i odkazy na „obdobné“ či ,přiměřené“ použití jiných ustanovení. V těchto případech , se vlastně obdoby uživá jako legislativní zkratky “ (HARVÁNEK, J. in: HARVÁ- 
případech se nejedná o ,vyplňování (protiplánové) mezery zákona, ale o rozvinutí možnosti, kterou zákonodárce výslovně předpokládal ". ${ }^{12}$

Schematicky můžeme popis i navrhovaná řešení mezer $\mathrm{v}$ zákoně cestou analogie znázornit, a to na základě doporučení, jež se nejčastěji objevují v tuzemských publikacích, následovně: ${ }^{13}$

(1) pro v právní praxi řešený př́pad neexistuje v pozitivním právu (či přesněji relevantním právním předpisu) normativní řešení;

(2) řešený právní př́ípad je však podobný či srovnatelný s př́ípadem, pro který existuje v platném právu normativní konsekvent;

(3) tudíž - majíc na zřeteli zejména zásadu de similibus idem est iudicandum (tj. podobné př́ípady posuzovat podobně), jež tvoří jeden z fundamentů formálního pojetí spravedlnosti, ${ }^{14}$ a úzce související požadavek hodnotové bezrozpornosti právního řádu ${ }^{15}$ - se na řešený př́ípad použije normativní konsekvent, se kterým normotvưrce počítal pro podobný/srovnatelný prípad.

Výše popsané schéma odpovídá tzv. analogii legis, což je jedna ze dvou základních forem arg. per analogiam, které jsou v právní vědě obvykle rozlišovány. ${ }^{16}$ Použití analogie - avšak s př́vlastkem ,právní“ (iuris) - přichází v úvahu rovněž v situacích, kdy v platném právu nenalezneme , „źádný pevný bod, od kterého bychom se mohli odrazit" .17 $V$ těchto př́padech bychom dle převládajícího názoru měli postupovat následovně:

(1) pro v právní praxi řešený př́ípad neexistuje v pozitivním právu (či přesněji relevantním právním předpisu) normativní řešení;

(2) daný právní př́ipad spadá svou povahou do právního odvětví, pro nějž jsou typické určité principy a hodnoty;

\footnotetext{
NEK, J. a kol. Právní teorie. Plzeň: Vydavatelství a nakladatelství A. Čeněk, 2013, s. 299), přičemž slovo „obdobně“ má vést k vyvození stejných právních následků a při „přiměřeném“ použití „, mají být vyvozeny jen některé následky“ (s. 297). Antecedent „obdobně“ či „přiměřeně“ aplikovaného ustanovení tak bude ve svém důsledku širší, než vyplývá z jeho jazykového znění.

12 SOBEK, Právní myšleni: kritika moralismu, s. 186. Za analogií intra legem, resp. i argumentem a simili (pokud je tedy odlišován od arg. per analogiam) prritom stojí podobné kognitivní mechanismy, což svědčí o širším využití analogického myšlení v právu (viz poznámka pod čarou č. 9, 82).

13 V tuzemských pramenech se lze setkat s nejrůznějšími schématy znázorňujícími analogii či jejími slovními uchopeními. Kupř́kladu J. Harvánek - bez jakékoliv legendy či vysvětlení proměnných - uvádí toto schéma: ,, $A+B: n=A+C: x$ “ (HARVÁNEK, c. d., s. 297). V téže publikaci L. Hlouch analogii vysvětluje rovněž následovně: ,"platí-li určitá vlastnost pro X, platí tato vlastnost i pro Y za predpokladu, že platí, že Xje podobné $Y^{\prime \prime}$ (s. 31). T. Sobek pak třeba rozebírá dílčí logické operace, které ve svém souhrnu tvoří analogický úsudek (SOBEK, Právni myšlení: kritika moralismu, s. 187).

14 PERELMAN, Ch. The Idea of Justice and the Problem of Argument. London: Routledge and Kegan Paul Limited, 1963, s. 16, 38, 40.

15 MELZER, c. d., s. 166; či obdobně WINTR, Metody a zásady interpretace práva, s. 164: „,použití analogie je... založeno na teleologických úvahách o predstavě a hodnotové koherenci právního ř́du ".

16 Analogie legis si všímá i tuzemský normotvůrce, který pro oblast soukromého práva vybízí k tomuto postupu: ,, Nelze-li právní prípad rozhodnout na základě výslovného ustanovení, posoudi se podle ustanovení, které se týká právniho př́padu co do obsahu a účelu posuzovanému právnímu prípadu nejbližšího " (\$ 10 odst. 1 obč. zákoníku).

17 MELZER, c. d., s. 247.
} 
(3) tudíž pro řešený prípad nalezneme právní konsekvent tak, že bude reflektovat právní principy a hodnoty, jež jsou př́značné pro danou výseč práva, není-li jich, pak bude zrcadlit obecné právní zásady, které jsou typické pro celý právní řád. ${ }^{18}$

Jako problematické je přitom obvykle vnímáno, kdy vlastně - v prípadě tzv. mezer v zákoně - přistoupit k analogickému usuzování, a kdy naopak je třeba preferovat argument a contrario či arg. per eliminationem..$^{19} \mathrm{Je}$ upozorňováno na riziko nahodilosti či dokonce arbitrárnosti volby jednotlivých argumentačních postupů ze strany orgánů aplikujících právo, což ve svém důsledku může vést $\mathrm{k}$ nepředvídatelnosti přijímaných rozhodnutí. ${ }^{20}$

Jedna z možností, jak minimalizovat toto riziko, spočívá dle mého soudu v kladení zvýšeného důrazu na náležitou argumentaci a zejména její přezkoumatelnost. ${ }^{21}$ Jinak řečeno, pouhé uvedení v odůvodnění rozhodnutí, že bylo argumentováno per analogiam, bez dalšího neospravedlňuje takto přijatý závěr, resp. může jej činit nepřezkoumatelným, což je v demokratickém právním státě nežádoucí.

Za legitimní proto považuji primárně taková rozhodnutí, která umožňují rekonstruovat a zpětně tak i přezkoumat celý postup, jenž vedl k určitému závěru přijatému cestou analogie. Mělo by být tedy vysvětleno, proč byla zvolena daná normativní konsekvence, resp. proč a $\mathrm{v}$ čem spočívá podobnost řešené věci a normativní hypotézy, která tento postup umožnila. $\mathrm{V}$ př́ípadě existence několika podobných normovaných skutkových podstat (nebot' i tyto př́pady nelze v praxi vyloučit), by mělo být vysvětleno, z jakých důvodů bylo upřednostněno některé $\mathrm{z} v$ úvahu přicházejících řešení. $\mathrm{V}$ neposlední řadě by mělo být rovněž vysvětleno, co vlastně $a d$ hoc rozhodlo o přistoupení k analogickému řešení př́ípadu.

V následujícím příspěvku bude těmto otázkám věnována bližší pozornost a bude též představen podrobnější model analogického usuzování, než tomu bylo ve dřive představených schématech. Konkrétně řečeno, bude prezentován model analogického usuzování/argumentace, ${ }^{22}$ jenž by mohl přispět - bude-li v praxi zohledněn - $\mathrm{k}$ lepší strukturaci, potažmo tedy ke zvýšení přesvědčivosti prijímaných rozhodnutí v řízeních,

18 Rovněž analogie iuris se dočkala svého zákonného vyjádření pro oblast občanského práva: „Neni-li takové ustanovení, posoudi se právni prripad podle principů spravedlnosti a zásad, na nichž spočivá tento zákon, tak, aby se dospělo se žretelem k zvyklostem soukromého života a s přihlédnutím k stavu právní nauky i ustálené rozhodovaci praxi k dobrému uspořádání práv a povinností “ (§ 10 odst. 2 obč. zákoníku).

19 Zmíněné argumenty se totiž tradičně kladou do opozice (SOBEK, T. Argumenty teorie práva. Praha: Ústav státu a práva, 2008, s. 138). Jak si všímají R. Procházka a M. Káčer, analogie, resp. i další tzv. logické argumenty, ,, dokážou s jistotou vyvodit určité závěry z předem daných premis. Vủbec ale [samy o sobě - pozn. aut.] nepomáhají s určením, které premisy máme postavit na začátek úsudku, resp. který z palety logických argumentù máme v konkrétním prípadě použit " (PROCHÁZKA - KÁČER, c. d., s. 245). Slovy T. Sobka, ,, neni těžké udělat A a neni těžké udělat non-A, těžké je najit presvědčivé dưvody k rozhodnutí, jestli udělat $A$, anebo udělat non- $A$. To je ten okamžik, kdy se láme chléb “ (SOBEK, Argumenty teorie práva, s. 139).

20 J. Harvánek kupříkladu varuje, že v případě analogie legis , se jedná o velmi kluzký nástroj..., který se může poměrně snadno vymknout (vědomě či nevědomě) svému účelu“ (HARVÁNEK, c. d., s. 298).

21 Obdobně: KNAPP, V. Védecká propedeutika pro právníky. Praha: EurolexBohemia, 2003, s. 21.

22 Po vzoru P. Barthy analogickým usuzováním zde rozumím specifický druh inference, který se opírá o analogii. Analogickou argumentací pak výslovnou reprezentaci formy analogického usuzování. Blíže: BARTHA, P. Analogy and Analogical Reasoning. In: ZALTA, E. N. (ed.). The Stanford Encyclopedia of Philosophy [online]. 25. 1.2019 [cit. 2020-05-05]. Dostupné na: https://plato.stanford.edu/entries/reasoning -analogy/. 
kdy dochází k dotváření práva cestou analogie (a to zejména analogie legis). Lze si od toho rovněž slibovat přijetí ad hoc racionálnějšího řešení, jemuž bude předcházet efektivnější nalézání argumentů ve prospěch i neprospěch, a to jak ve fází nalézání práva, tak i ex post facto při kritickém rozboru určitého případu, at’ už ve fázi přezkumu ze strany odvolacího orgánu, či v rámci vědecké práce. ${ }^{23}$

\section{K ANALOGICKÉ SITUACI V PRÁVU}

Jak bylo naznačeno, analogie může plnit dvě základní role, jednak heuristickou, jednak - při splnění určitých podmínek - i legitimizační. ${ }^{24}$

Co se týče první z jmenovaných funkcí, heuristické, tak pomocí analogie získáváme „,nové premisy ohledně určité kauzy, kde chybi (zákonná) pravidla “. ${ }^{25}$ Otevírá tedy nové možnosti, jak uchopovat daný problém. ${ }^{26}$

K relevanci závěr/ů získanému/ým cestou analogie můžeme přitom přistupovat dvojím způsobem, bud' „probabilisticky“, tj. subjektivně je/j vnímat jako tím pravděpodobnější, čím větši míru podobnosti shledáváme mezi srovnávanými př́ípady, a přiklonit se - je-li zdrojových príípadů více - $\mathrm{k}$ tomu závěru, který pramení z př́ípadu nejpo-

${ }^{23} \mathrm{~K}$ zastávané tezi, že formální reprezentace ,,významné prispivá k vyhodnocení cností a negativ takto strukturovaných argumentũ, včetně jejich silných a slabých mist “ (BREWER, S. From Enthymeme to Argument: Logocratic Method and the Virtues and Vices of Arguments. In: WEINSTEIN, J. B. - ABRAMS, N. - BREWER, S. - MEDWED, D. S. Evidence: Cases and Materials. 10th ed. Foundation Press, 2017, s. 121) srov. zejména práce zde citovaného autora věnované tzv. logokratické metodě. V tuzemském právním prostředí obdobný závěr zastává L. Hlouch, dle kterého „,rozpoznání charakteru právnického úsudku, který vede $k$ výkladovému závěru, je ... velmi prospěšné k pochopení di̊vodů, na nichž právni výklad [sic!, v rámci pojednání o analogii - pozn. aut.] spočívá, a může sloužit $k$ odhalení slabiny či logické chyby v právní interpretaci, které mohou vést $k$ nesprávnosti výkladového závěru " (HLOUCH, L. in: HARVÁNEK, c. d., s. 341). Připomíná však, že v právní praxi zpravidla právníci nesignalizují, jaké inference stojí za jejich argumentací (tamtéž).

24 Budeme-li po vzoru H. Reichenbacha rozlišovat mezi „kontextem objevu“ a „kontextem ospravedlněni“, tak $\mathrm{s}$ analogií můžeme mít co do činění v obou těchto souvislostech. Tato teze však není obecně akceptována. K přehledu rozdílných názorů na tuto otázku srov. BREWER, S. Indefeasible analogical argument. In: KAPTEIN, H. - VELDEN, B. VAN DER (eds.). Analogy and Exemplary Reasoning in Legal Discourse. Amsterdam: Amsterdam University Press, 2018, s. 36 a násl.

25 PRAKKEN, H. Logical Tools for Modelling Legal Argument: a Study of Defeasible Reasoning in Law. Dordrecht: Kluwer Academic Publishers, 1997, s. 28. Samotný Prakken ale nepovažuje analogii za formu usuzování, ale jen ,, heuristickou zásadu“ (s. 29), a tudíž se nemůže dle jeho soudu objevit v rámci „,kontextu ospravedlnění“. Většinový názor je však takový, že analogie představuje zvláštní typ induktivního úsudku. Od klasické indukce se však liší hlavně v tom, že od konkrétní premisy (příkladu) docházíme ke konkrétnímu závěru (u indukce je to obecný závěr), a to jak již upozorňoval Aristoteles (viz výše - poznámka pod čarou č. 1). Další významný rozdíl spočívá v podmínkách, kdy jsme nuceni odmítnout závěr. Máme-li co do činění s indukcí, stačí, že jedna premisa týkající se vlastností určitého objektu se liší od ostatních premis, což vede k odmítnutí celého úsudku. U analogie - dalo by se říct „definičně“ - se ale počitá s tím, že určité vlastnosti porovnávaných objektů jsou odlišné. Naznačené rozdíly jsou dle některých autorů (např. S. Brewer) natolik zásadní, že vyčleňují analogii jako samostatný druh - vedle dedukce, indukce a abdukce - usuzování. K rozdílům mezi indukcí a analogí srov. blíže: MALINOWSKI, A. (ed.). Logika dla prawników. Warszawa: LexisNexis, 2010, s. 198-199. K důvodům, proč „,metoda analogická“ bývá řazena k „metodě induktivní“, pak srov. TVRDÝ, J. Logika. Praha: Melantrich, 1937, s. 121, 178 a násl.

${ }^{26}$ Po vzoru J. Tvrdého lze dodat, že ,, analogie jest také základem, na němž vznikaji vyšši a širšsi hypothesy“ (TVRDÝ, c. d., s. 167), což v oblasti práva mj. znamená, že přispívá k identifikaci obecných zásad stojících za určitou tř́idou př́ípadů (srov. dále). 
dobnějšího námi posuzované věci; anebo „modálně“, tj. jako dostatečný závěr, jenž je způsobilý $\mathrm{k}$ tomu, aby byl podroben dalšímu testování, resp. půjde o konkluzi, kterou lze považovat jako adekvátnější než jiná v úvahu přicházející ř řšení dané věci, což ale je ověřováno. 27

Aby analogie plnila legitimizační funkci, tj. obstála i v kontextu justifikace, je nezbytné ukázat strukturu a vlastnosti analogické argumentace. Jinak řečeno, mám za to, že je třeba v rámci odůvodnění představit její „logickou formu“, kterou po vzoru S. Brewera lze chápat jako ,průkazný vztah mezi premisami argumentu a jeho závěrem " ${ }^{28}$ Nestačí tedy cestou analogie získaný závěr bez dalšího a de facto nepřezkoumatelně přijímat (a to třeba i s poukazem na blíže nevysvětlenou podobnost dvou př́padů), nýbrž je třeba k němu zaujmout „modální“ postoj a vysvětlit, proč lze přijaté řešení považovat za nejvhodnější, a tedy i ukázat, proč obstálo v rámci následného ověřování (např. v testu teleologické legitimity - viz níže).

Pozornost orgánů aplikujících právo by přitom měla být vždy věnována v prvé řadě tomu, zda vůbec máme co do činění se situací, kdy je na místě přistoupit $\mathrm{k}$ analogickému usuzování. Jak jsme uvedli výše, ,, analogie má vyplňovat [pouze - pozn. aut.] určité ,mezery v právu“".29

Narážíme zde na netriviální problém, zda, resp. při jakém pojetí práva, lze vůbec o „mezerách v právu“ hovořit. ${ }^{30}$ Přijmeme-li dnes rozšriřený názor, že právo sestává jednak z pravidel (právních norem), jednak z principů, které i přes vysokou míru abstrakce mají regulativní charakter ${ }^{31} \mathrm{a}$, uplatni se ..., pokud jiný právní standard $v$ dané situaci neváže více ", 32 je otázkou, zda lze vůbec hovořit o mezerách v právu, resp. zda vůbec existuje prostor pro dotváření práva cestou analogie. ${ }^{33}$ Také z tohoto důvodu v právní

27 K danému členění srov. BARTHA, $c . d$.

28 BREWER, Indefeasible analogical argument, s. 34, poznámka pod čarou č. 2. Nutno však dodat, že sousloví „logická forma argumentace“ lze interpretovat rưzně. V nejužším slova smyslu jde o formálně-logické schéma vyjádřené ve formalizovaném jazyku (např. predikátové logiky), jež zachovává pravdivost či platnost úsudků v rámci daného logického systému. Ve volnějších významech jde o schematizaci argumentace (od premis k závěrům), jejíž platnost se odvíjí od způsobu vyjádření argumentů a v rámci nich založených vztahů. Konečně - nejvolněji - můžeme za logickou formu označit i schéma, ve kterém jsou užívány symboly (proměnné, konstanty) místo běžného jazyka. S. Brewer vychází přitom z druhého možného pojetí. $\mathrm{K}$ „logické formě“, resp. k různému pojetí „formálních způsobů úsudků“ srov. BROŻEK, B. Is Analogy a form of legal reasoning? In: KAPTEIN, H. - VELDEN, B. VAN DER (eds.). Analogy and Exemplary Reasoning in Legal Discourse. Amsterdam: Amsterdam University Press, 2018, s. 54.

29 GERLOCH, c. d., s. 145. Jak k tomu výstižně dodává F. Melzer, ,, existence této mezery v zákoně [sic! pozn. aut.] je zásadně též mezi analogické aplikace" (MELZER, c. d., s. 152).

$30 \mathrm{~K}$ názorům popírajícím existenci mezer v právu srov. WEINBERGER, O. Norma a instituce: úvod do teorie práva. Brno: Masarykova univerzita, 1995, s. 172 a násl.; či třeba VEČEŘA, c. d., s. 228 a násl.

31 „Každý princip musí být schopen sdělit, co podle něj má být (dispozice) a na jaké faktické situace se vztahuje (hypotéza) “(WINTR, J. Řiše principư: obecné a odvětvové principy současného českého práva. Praha: Karolinum, 2006, s. 103).

32 Tamtéž, s. 101. Jak totiž dále připomíná J. Wintr, ,, každý právni princip má... na rozdíl od právní normy... otevrený antecedent" (s. 101).

33 I kdybychom akceptovali názor, že právní normy tvoří otevřený normativní systémem, tak právní principy doplní právní řád do logicky uzavřeného systému. Otázka otevřenosti či uzavřenosti práva je zde posuzována z hlediska jeho aplikace. Stranou úvahy jde tedy hodnocení práva z pohledu jeho tvorby, a to např́íklad prizmatem Luhmannovy koncepce práva jako autopoietického systému. 
teorii zaznívají názory, že , vždy, kdy principy upravují př́pady, bezprostředně vylučují analogii a neponechávají pro ni prostor... ". 34

Pokud bychom akceptovali tento pohled, je nasnadě, že k využití analogie by docházelo jen ve zcela výjimečných a spiše nepravděpodobných př́ipadech. ${ }^{35}$ Nicméně tento postoj lze dle mého soudu úspěšně verifikovat, a to pokud zohledníme, že samotný zákonodárce často sám vybízí k použití analogie, a to jsou-li pro to splněny stanovené podmínky.

V tuzemském právu tak např́íklad normotvưrce vybízí $\mathrm{k}$ analogickému dotváření práva $\mathrm{v}$ oblasti občanského práva $\mathrm{v}$ situacích, $\mathrm{kdy}$,,nelze() právní př́pad rozhodnout na základě výslovného ustanovení... ", tj. existuje-li mezera v zákoně, a ne v právu. ${ }^{36}$ $\mathrm{V}$ těchto př́ípadech má pak dotváření práva cestou analogie přednost před aplikací právních principů.

Zákonná normativní ustanovení jsou totiž vždy výsledkem předchozího vážení principů, které v rámci normotvorby realizoval zákonodárce, a to sice ne ve vztahu $\mathrm{k}$ ad hoc soudem posuzovanému př́padu, nýbrž $\mathrm{k}$ danému rodu prŕpadů. ${ }^{37} \mathrm{Jinak}$ řečeno, $\mathrm{v}$ rámci tvorby práva je potencionální „,bezbřehost“ použitelných právních principů na určitý typ situací zužována jen na některý/é z nich.

Smyslem analogie je tedy zaručit, aby - slovy důvodové zprávy k občanskému zákoníku - ,v zákoně [byl nalezen - pozn. aut.] i jeho latentní obsah “, jinak - budou-li bez dalšího použivány obecné zásady právní - ,to může vést $k$ nepredvídatelným závěrům a arbitrární libovưli “ “ ${ }^{38}$ Dotvoření práva dle analogie legis má zajistit, že když se „,přihodí něco mimo povšechného, a tehdy je správné, aby tam, kde zákonodárce, poněvadž mluvil všeobecně, něco opominul a pochybil, opomenutí opraviti, jak by řekl i sám zákonodárce, kdyby byl př́tomen a jak by ustanovil, kdyby o tom věděl “. 39

Teprve nenalezneme-li v platném právu vhodné ustanovení $\mathrm{k}$ analogickému uplatnění, pak je namístě zohlednění posuzované věci prizmatem právních principů (zejména spravedlnosti) a ,zásad, na nichž spočivá tento zákon “ (§ 10 odst. 2 obč. zákoníku). Nicméně i v př́padě postupu dle analogie iuris soudce nemůže zcela svobodně volit ze všech v úvahu přicházejících principů, nebot' normotvůrce mu ukládá zohlednit ,,zvyklosti soukromého života, stav právni nauky, ustálenou rozhodovací praxi“ ( 10 odst. 2 obč. zákoníku), aby výsledkem bylo dobré uspořádání práv a povinností. ${ }^{40}$

34 DUARTE, D. Analogy and Balancing: the Partial Reducibility Thesis and Its Problems. In: KAPTEIN, H. VELDEN, B. VAN DER (eds.). Analogy and Exemplary Reasoning in Legal Discourse. Amsterdam: Amsterdam University Press, 2018, s. 99.

35 Dle Duarteho tomu bude za těchto okolností: (i) neexistuje ani pravidlo, ani princip, dle kterého by bylo možné př́ípad posoudit; (ii) pravidlo obsahuje důsledek, který nebyl upřesněn pro kategorii, která rovněž spadá do její působnosti (DUARTE, c. d., s. 98).

36 Již ze samotné textace hlavy 1, dílu 1 občanského zákoníku přitom evidentně plyne, že zákonodárce nezužuje právo pouze na právo pozitivní.

37 BROŻEK, B. Analogy and Balancing: a Reply to David Duarte. In: KAPTEIN, H. - VELDEN, B. VAN DER (eds.). Analogy and Exemplary Reasoning in Legal Discourse. Amsterdam: Amsterdam University Press, 2018, s. 99.

38 Důvodová zpráva k $§ 10$ (nového) občanského zákoníku [online], s. 41. [cit. 2020-05-05]. Dostupné na: http://obcanskyzakonik.justice.cz/images/pdf/Duvodova_zprava_leden_2011_.pdf.

39 ARISTOTELES. Etika Nikomachova. Praha: Petr Rezek, 1996, s. 146.

40 Tyto subsidiární prameny, jež mají být zohledněny při výběru normativního konsekventu, brání soudu, aby bez dalšího rozhodl dle libovolného právního principu či svého pocitu spravedlnosti. Lze proto souhlasit 
Uvedené legitimizuje závěr, že analogie legis je ve vztahu speciality k analogii iuris. Dotváření práva cestou analogie iuris se pak liší od rozhodování na základě principu spravedlnosti či předem neidentifikovaných právních principů a zásad. Obecněji analogii můžeme chápat jako nástroj, jenž má zajištovat přiměřenost soudcovského dotváření práva a současně bránit aplikační libovůli. Jde tedy o způsob generování „nových premis“, jejichž podoba je ale a priori jistým způsobem předurčena.

Mlčení zákonodárce (a nikoliv tedy práva jako takového) ohledně určité situace však může pramenit z řady důvodů (např. to bylo jeho záměrem, nebot' nebylo možné v legislativním procesu dosáhnout konsensu ohledně způsobu řešení určité otázky). Namístě je proto vždy důkladné prozkoumání př́íčin mlčení zákonodárce, a to například na základě interpretace př́ípravných materiálů z doby vzniku relevantního normativního textu (např. stenografických zápisů z projednávání ve Sněmovně, důvodových zpráv). Lze proto rovněž přisvědčit názoru I. Pelikánové, že je třeba vždy posoudit, ,zda zákonodárce mlčel, protože situaci upravit nechtěl (chování mělo být dovoleno, povinnost neměla být uložena), nebo protože na ni nepomyslil. Ve druhém př́padě půjde o mezeru $v$ zákonè, již bude nutno zaplnit. "41

Je třeba ale mít na paměti, že možnosti dotváření práva cestou analogie nejsou ve všech subsystémech právního řádu totožné. Přesněji řečeno, normotvůrce pro některá právní odvětví může výslovně či nepř́imo vyloučit použití právní analogie (typicky $\mathrm{v}$ trestním právu hmotném nelze $\mathrm{v}$ neprospěch osob rozšiřovat skutkové podstaty trestných činů či druhy trestů; ${ }^{42}$ či v daňovém právu nelze rozšiřovat okruh prŕpadů, kdy lze vybírat daň nebo ukládat sankce ${ }^{43}$ ). Je nasnadě, že nebude možné dopad trestněprávních či daňových předpisů rozšiřovat ani cestou aplikace právních principů, a to mj. vzhledem k významnosti zásad Nullum crimen, nulla poena sine praevia lege poenali a Nullum tributum sine lege. ${ }^{44} \mathrm{Z}$ téhož důvodu nelze ani uvažovat o teleologické extenzi. ${ }^{45}$

\footnotetext{
s J. Tryznou, že ,,kritérium spravedlnosti má mit zcela subsidiární úlohu a lze jej využít až v př́padě, $k d y$ neni žádný jiný pramen pravidel pro rozhodnutí určitého prípadu “ (TRYZNA, J. Garance právní jistoty z hlediska metodologie interpretace práva předvídané novým občanským zákoníkem. In: GERLOCH, A. TRYZNA, J. - WINTR, J. (eds.). Metodologie interpretace práva a právní jistota. Plzeň: Vydavatelství a nakladatelství A. Čeněk, 2012, s. 204).

41 PELIKÁNOVÁ, I. Komentář k § 10 NOZ. In: ŠVESTKA, J. - DVOŘÁK, J. a kol. Občanský zákoník: komentár. Sv. 1. Praha: Wolters Kluwer ČR, 2014, s. 47. Normotvůrce obvykle reguluje standardní, typizované př́ípady, a tak určitá atypická situace může uniknout jeho pozornosti. Další z důvodů vzniku proti-plánových mezer může pramenit z toho, že „prudký rozvoj postmoderni společnosti... přinášsi nové situace a předkládá před právo nové - jím dosud vủbec nepredvídané- problémy k řešení. Je proto namistě [zejména cestou analogie iuris - pozn. aut. ] pootevřit prostor k řešení takových př́padì, na něž aktuální úprava nepamatuje a pamatovat nemůže " (Důvodová zpráva $\mathrm{k} \S 10$ obč. zákoníku, s. 41).

42 Srov. čl. 39 Listiny základních práv a svobod: „,Jen zákon stanoví, které jednání je trestným činem a jaký trest, jakož i jaké jiné újmy na právech nebo majetku, lze za jeho spácháni uložit. “, jakož i ustanovení § 12 odst. 1 tr. zákoníku: „Jen trestni zákon vymezuje trestné činy a stanoví trestni sankce, které lze za jejich spáchání uložit. "

43 Cll. 11 odst. 5 Listiny základních práv a svobod: „Daně a poplatky lze ukládat jen na základě zákona. “

44 Srov. též: MORAWSKI, L. Zasady wyktadni prawa. Toruń: Dom Organizatora, 2010, s. 228.

$45 \mathrm{~V}$ úvahu nanejvýš přichází použití extenzivního jazykového výkladu. Pomyslnou nepřekročitelnou mezí tak bude hranice nejširšího možného jazykového významu daného ustanovení. K vzájemnému vztahu analogie na straně jedné a extenzivního výkladu na straně druhé srov. CANALE, D. - TUZET, G. Analogical Reasoning and Extensive Interpretation. In: KAPTEIN, H. - VELDEN, B. VAN DER (eds.). Analogy and Exemplary Reasoning in Legal Discourse. Amsterdam: Amsterdam University Press, 2018, s. 65-84.
} 
Ukáže-li se však, že vstupní podmínka pro analogickou argumentaci je splněna, a tedy že tento způsob usuzování je aprobovaný v daném právním odvětví (či jeho výseči) ${ }^{46}$ a že máme co do činění s relevantní (tj. proti-plánovou) mezerou v zákoně, lze přistoupit k vlastnímu analogickému úsudku. Jako nanejvýš žádoucí se přitom jeví, aby normotvůrce zaujal jasný postoj $\mathrm{k}$ prŕípustnosti analogie $\mathrm{v}$ daném subsystému práva, čímž může předejít případným aplikačním problémům. ${ }^{47}$ Taktéž zkvalitněním jazykového znění prrijímané právní regulace lze snižit výskyt těchto obtíží.

Správné vyhodnocení popsané vstupní fáze analogického úsudku je přitom o to zásadnější, že rozhodnutí o př́pustnosti , užití analogie... vylučuje argumentum a contrario a vice versa. Tento argument (a contrario) ... není samostatným argumentem, nýbrž je závislým na př́pustnosti analogie. Jeho užití tak vlastně implicitně vypovidá, že analogie v konkrétním prípadè neni prípustná. "48

Použití arg. a contrario bude tak přicházet v úvahu v situacích, kdy posuzovaný př́ípad nelze úspěšně podřadit pod žádný normativní antecedent (je za hranicí jazykového významu), což ale i odpovídalo záměru autora, a současně to nezakládá bezdůvodnou rozdílnost $\mathrm{v}$ právním postavení osob ocitajících se $\mathrm{v}$ obdobném postavení. Pokud normotvůrce o určité situaci nemohl vědět, popř. ji bezdůvodně opominul či upravil hodnotově nekonzistentně, ${ }^{49}$ a současně je třeba - vzhledem k zákazu denegatio iustitiae - ve věci rozhodnout, je namístě postup per analogiam (a to za předpokladu, že tomu nebrání obecný zákaz analogie $\mathrm{v}$ daném subsystému práva či jeho výseči).

\section{K MODELU゚M ANALOGIE}

V rámci právní teorie i logiky byla navržena celá řada schémat analogického usuzování. Nicméně doposud nebyla navržena taková striktně formálně-logická reprezentace, která by byla s to - skrze objektivní a obecná formální pravidla - strukturovat všechny kroky (včetně prováděných voleb) tohoto úsudku, tj. ,, aniž by tedy bylo nutné se v nějaké fázi dovolávat intuice ". ${ }^{50}$ Ve svém důsledku to vede $\mathrm{k}$ tomu, že jsou

46 I v rámci občanského práva můžeme najít oblasti, ve kterých analogie není namístě. Důvodová zpráva k obč. zákoníku kupříkladu výslovně zmiňuje „statusové otázky“, byt’ současně nevylučuje, že i zde dotváření práva cestou analogie iuris bude myslitelné, pokud budoucí vývoj společnosti přinese problémy, které nebylo možné v době normotvorby předjímat. Blíže: Důvodová zpráva k $§ 10$ obč. zákoníku, s. 41.

47 Nezaujme-li normotvůrce jasné stanovisko $\mathrm{k}$ přípustnosti analogie $\mathrm{v}$ daném právním odvětví či dílčí oblasti práva, je namístě vycházet $\mathrm{z}$ názorů představitelů právní doktríny a vyšších soudů. Doktrína se přitom obvykle kloní $\mathrm{k}$ tomu, že dotváření práva cestou analogie je vyloučeno - kromě výše uvedených príkladů i v oblasti správního trestání, pravomocí a kompetencí státních orgánů (VEČĚ̌A c. d., s. 232-233), dále napríílad co se týká rozsahu povinností ukládaných normotvůrcem soukromým subjektům, a to na rozdíl od jejich subjektivních práv a svobod (MORAWSKI, c. d., s. 223-228).

48 MELZER, c. d., s. 244.

49 I výskyt tzv. hodnotové (teleologické, axiologické) mezery v zákoně může legitimizovat potřebu aktivního zásahu soudce v aplikačním procesu. Půjde o př́ípady, kdy výklad opírající se např. o $\arg$. a contrario nevede k uspokojivému výsledku, nebot' narušuje hodnotovou koherenci právního řádu. Blíže např. VEČEŘA, c. $d$., s. 230-231; MELZER, $c$. d., s. 225 et passim. Ukazuje se přitom, že v aplikačních procesech je namístě se vždy dívat za normativní text, tj. zohlednit i účel úpravy, hodnoty, které odráží, základní právní principy (srov. dále).

50 NORTON, $c . d$., s. 2. 
navrhovány bud' stále propracovanější modely a pravidla ovládající analogické usuzování a argumentaci, anebo nová pojetí analogie, která by se vyhnula nutnosti formulovat obecná kritéria ovládající výběr jednotlivých premis analogického úsudku, a to nezávisle na jejich konkrétním obsahu. ${ }^{51}$

Uvedené lze ilustrovat na vývoji názorů na formální schematizaci tohoto typu úsudku: Až do 20. století se lze setkat s poměrně jednoduchými schématy, která jsou inspirována strukturou sylogismů. Např́klad G. H. Joyce, autor populárního kompendia věnovaného tradiční logice ze začátku 20. století, navrhoval toto schéma:

$\mathrm{S} 1$ je $\mathrm{P}$

S2 připomíná S1 v tom, že je M.

(Tudíž) S2 je P. ${ }^{52}$

Současně k tomu dodal, že relevance této inference se bude odvíjet od toho, zda existuje mezi M a P kauzální vztah. Pokud skutečně existuje, pak jde o platný úsudek, jinak není vůbec namístě (byt' S2 je M) dovozovat, že je také P. ${ }^{53}$

Takové pojetí analogie naráží na řadu problémů: V době činění analogického úsudku mnohdy nejsme s to zjistit, zda existuje tento kauzální vztah, a to do doby, než bude tato spojitost empiricky prokázána. ${ }^{54}$ Navíc správnost závěru, jenž byl přijat na základě ,plané“ analogie, není automaticky zpochybněna tím, že se ex post facto vyvrátilo kauzální spojení (anebo že toto neexistuje). ${ }^{55} \mathrm{~V}$ oblasti práva a jeho aplikace je pak třeba zejména upozornit na skutečnost, že v rámci argumentace per analogiam není namístě hovořit o kauzální spojitosti mezi sdílenou vlastností či strukturou daného případu a zdrojem analogie (např. zákonnou hypotézou) na straně jedné a normativním konsekventem na straně druhé. (Relevantní) podobnost srovnávaných objektů tedy bez dalšího nepředstavuje objektivní kauzální důvod pro dotvoření práva cestou analogie. Je sice ,vysvětlujícím a zároveň ospravedlňujícím di̊vodem "56 pro tento postup (tedy dotvoření práva cestou analogie), ale jeho obecná vhodnost a přesvědčivost se bude odvíjet jednak od toho, zda byla adekvátně vyhodnocena a odůvodněna otázka přípustnosti analogie, jednak od odůvodnění stojícího za volbou a výkladem určitého zdroje analogie (viz níže).

51 Nemožnost nalezení zcela objektivních kritérií dle některých ospravedlňuje názor, že analogie nemá skutečně formálně-logickou povahu, což vede k umenšování relevance takto získaných výsledků.

52 JOYCE, G. H. Principles of Logic. 3rd ed. London: Longmans, Green and Co, 1936, s. 260. Obdobně byt' pomocí slov - pojímal analogii J. S. Mill, dle kterého , dvě věci jsou si podobné v jednom nebo více ohledech; jisté tvrzení je pravdivé o jedné z nich, tudiž je i pravdivé pro druhou (věc) “ (MILL, J. S. A System of Logic: Ratiocinative and Inductive: Being a Connected View of the Principles of Evidence, and the Methods of Scientific Investigation. 8th ed. New York: Harper and Bros, 1882, s. 684). K analogii v díle Milla srov. TVRDÝ, c. d., s. 120.

53 JOYCE, c. d., s. 260. Tímto dovětkem tak doplňuje svoje původní schéma o stěžejní podmínku - kauzální spojení mezi M a P.

$54 \mathrm{~K}$,planým“ analogiím v dějinách přírodních věd, jež vedly k nutnosti korigovat původní schéma, srov. NORTON, $c . d$., s. 5 a násl.

55 U analogií, jež se neopírají o kauzální souvislost, a to alespoň co se přírodních věd týká, lze však předpokládat jejich nižší pravděpodobnost než u analogií, kde tento vztah existuje. Blíže: NORTON, c. d., s. 5.

56 SOBEK, Právní myšlení: kritika moralismu, s. 188. 
Objevily se proto požadavky, aby v rámci analogických schémat byly zohledňovány další aspekty, které umožní odlišit životaschopné analogie od těch „zdánlivých“. Nelze prritom ale zapomínat, že dle většinového názoru lze cestou analogie přijmout vždy jen vyvratitelné (defeasible) závěry, které nikdy nebudou garantovat jistotu dedukčních úsudk‥ ${ }^{57}$ Nicméně i v tomto ohledu platí pro právní analogie dílčí odchylka: Je-li určitá analogie (výsledek analogické argumentace) respektována danou právní komunitou, stává se skutečností. Na rozdíl tedy od př́rodních věd, konsenzus ohledně závěrů přijatých cestou analogie ze strany relevantní právní komunity vede $\mathrm{k}$ tomu, že takto přijatý závěr může postupně v právním prostředí sedimentovat. ${ }^{58}$ Jinými slovy, ,, analogie tu není pracovni hypotézou, kterou podrobujeme experimentální kontrole, jak je tomu ve vědě, ale její přijetí ústí do [právních - doplněno aut.] ... koncepcí skutečnosti strukturovaných cestou analogie". 59

Klíčová otázka, která se tak vynořuje, zní, jak zvýšit relevantnost analogických úsudků. Nejde přitom o žádnou novou otázku, zohledníme-li fakt, že hlavním cílem, ke kterému se již od dob Aristotela upíná snažení různých myslitelů zkoumajících analogii, je ,"nalézt formální kritéria, která by umožňovala odlišit dobré od špatných analogii" “. ${ }^{\circ}$

Odpovědi jdou dvojím směrem: zaprvé, velká pozornost musí být věnována výběru opravdu podobných príípadů, zadruhé, se objevují volání, že spolu s hledáním obdobných případů by měly být hledány obecnější zásady (pravidla, zásady či hodnoty) stojící za rozhodovaným př́ípadem.

\section{K (NE)PODOBNOSTI PŘÍPADU゚}

Jeden z nejdiskutovanějších momentů analogických úsudků je určení, kdy vlastně máme co do činění s podobností určitých dvou či více objektů/situací/jevů apod. V oblasti práva se tedy budeme ptát, zda dva (či více) ,př́ípady“ jsou si navzájem podobné. Srovnávané objekty (normativní hypotéza a ad hoc skutková podstata) však nesmí být totožné (identické), ${ }^{61}$ jelikož pak by byla namístě subsumpce daného případu pod danou právní normu, tj. aplikace normativního konsekventu cestou dedukce. Pro analogii by zde nezůstával již žádný prostor. ${ }^{62}$

V závislosti na typu právní kultury se přitom bude částečně lišit to, co vlastně je předmětem srovnávání a jakou variabilitu těchto objektů budeme mít k dispozici.

57 Zaznívají však i opačné názory, dle kterých v určitých a spíše nečetných př́ípadech může mít analogie (analogický argument) sílu deduktivního úsudku. Srov. blíže: BREWER, Indefeasible analogical argument, s. $35-48$.

58 Jak tedy výstižně upozorňuje T. Sobek, ,,[p]lauzibilita právního myšlení není testována objektivní realitou, jak je tomu u přirodovédního myšlení, ale právní autoritou “(SOBEK, Právni myšlení: kritika moralismu, s. 188).

59 PERELMAN, CH. Právna logika: nová rétorika. Bratislava: Kalligram, 2014, s. 180

60 NORTON, c. d., s. 1.

61 „Uvažované objekty se tedy musí lišit aspoñ v jednom znaku, (nebot') ... analogie je úsudek založený na stanovení podobností dvou různých objektů " (ŠTĚPÁN, J. Logika a právo. 3. vyd. Praha: C. H. Beck, 2011, s. 60).

62 „Homogenita je nepoužitelná v rámci analogie, jejiž epistemologická funkce lépe poznat, strukturovat nebo hodnotit tému pomoci fory, predpokládá heterogennost prvkủ “ (PERELMAN, Právna logika: nová rétorika, s. 180). 
V kontinentální právní kultuře pro ad hoc posuzovaný př́ípad (cíl, target) budeme primárně hledat „obdobný“ či „,přiměřený“ protějšek či protějšky (zdroj/e, sources) v normativním právním textu, resp. v jeho hypotézách. V anglosaském typu právní kultury budeme hledat „obdobná“ či „,srovnatelná“ dřívější rozhodnutí soudů, tj. předchozí precedenty s obdobným věcným rozsahem. Je přitom nasnadě, že v zákonných právních textech používané relativní neurčité formulace umožňují pokrýt větší výseč v realitě potencionálně vznikajících případů (tj. určitou jejich třídu), než je tomu u precedentů. Současně nelze opominout, že rovněž v systému kontinentálního práva je namístě v rámci nalézání práva (at' cestou interpretace, či dotváření) zkoumání předchozí rozhodovací praxe, která sice není pro soudce formálně závazná, nicméně vzhledem k požadavkům formální spravedlnosti (rovnosti) a předvídatelnosti práva, by měla být v rozhodnutí reflektována. ${ }^{63}$ Jak jsme viděli výše, v souvislosti s úpravou analogie iuris $\mathrm{v}$ textu občanského zákoníku normotvůrce tuto povinnost výslovně zopakoval. Ukazuje se tak rovněž, že zkoumání otázky podobnosti má v právní praxi podstatně širší využití i význam. ${ }^{64}$

Bez ohledu na to, zda zdrojem analogie bude obdobná zákonná hypotéza či dřívější soudní precedens, logikové s oblibou upozorňují, že dvě věci se teoreticky vždy můžou lišit v nekonečném množství aspektů. Současně ale jsou si podobny ve stejně nekonečném množství ohledů. ${ }^{65}$

O podobnosti dvou objektů lze přitom hovořit již ve chvíli, kdy existuje alespoň jedna věta popisující daný objekt či jeho vlastnosti, vztahy, funkce (souhrnně „doménu“), která platí jak pro cíl, tak i potencionální zdroj. ${ }^{66}$

Vzniká tak kruciální otázka, ,,v jakých vlastnostech (pojmových znacích), prípadně v jakém počtu těchto vlastností (pojmových znakư) si mají být X a Y podobné "67 (popř. i více potencionálních zdrojů)? Jinak řečeno, „které momenty jsou podstatné pro to, aby dva prípady byly regulovány stejně a jaké rozdily si vyžaduji rozdílné právní ná-

63 Tento požadavek se recentně dočkal i svého normativního vyjádření, a to konkrétně v $\S 13$ občanského zákoníku (část do středníku): „Každý, kdo se domáhá právní ochrany, mưže di̊vodně očekávat, že jeho právní prípad bude rozhodnut obdobně jako jiný právni př́pad, který již byl rozhodnut a který se s jeho právním prípadem shoduje v podstatných znacích; .... “.

64 Vždy, když soudce hledá či vybírá dřívější rozhodnutí, která jsou pro aktuálně projednávaný případ relevantní, měl by se zabývat otázkou podobnosti a rozdílnosti skutkových okolností daného případu s předchozími rozhodnutími. Jak správně upozorňuje T. Smejkalová, ,, kontext (a to nejen právní, ale i skutkový) může ovlivňovat význam práva“, přičemž je-li ,, interpretace soudu používána mimo svůj původní skutkový kontext, v jehož rámci má smysl, může... docházet $k$ informačnímu deficitu, který posléze může vést k významovým posunům... Není možné (proto) automaticky akceptovat dekontextualizovanou judikaturu jako legitimni" (SMEJKALOVÁ, T. Judikatura, nebo precedens? Právník. 2019, č. 9. In: Codexis: Atlas Consulting [online]. [cit. 2020-05-05]).

65 GOODMAN, N. Problems and Projects. New York: Bobbs-Merril Co, 1972, s. 443, popř. ve vztahu k právu: WHITE, J. Analogical reasoning. In: PATTERSON, D. (ed.). A Companion to Philosophy of Law and Legal Theory. Blackwell Publishing Ltd, 1999, s. 585.

66 BROŻEK, B. Analogy in Legal Discourse. Archiv fur Rechts-und Sozialphilosophie. 2008, Vol. 94. No. 2, s. 198. Citovaný autor vychází z toho, že objekty právního srovnávání jsou stavy věcí, a tudíž je lze popsat. Každý popis skutkového stavu pak lze považovat za soubor vět. Můžeme k tomu dodat, že orgány aplikující práva se v soudních síních nesetkávají se skutky jako takovými, ale vždy s jejich popisy.

67 HLOUCH, L. in: HARVÁNEK, c. d., s. 341. 
sledky “?68 Jejímu zodpovězení však bývá ze strany právníků obvykle věnována menší pozornost, a to na rozdíl od logiků.

Za průlomovou lze označit zejména práci Mary B. Hesse Models and Analogies in Science z roku 1963, která obohatila diskuzi na toto téma o koncepci „pozitivních a negativních analogií“, jejichž rozlišování přebírá z díla J. M. Keynese. O pozitivní analogii lze hovořit, pokud srovnávané vlastnosti/vztahy/prvky „,zdrojové“ domény i „cílové“ domény se shodují, kdežto negativní analogií se rozumí ty vlastnosti/vztahy/ prvky, ve kterých se zdrojové a cílové domény liší. ${ }^{69}$ Za účelem zhodnocení síly určitého závěru získaného cestou analogie pak M. Hesse mj. navrhuje, aby byly porovnány pozitivní a negativní analogie, jakož i celkový poměr mezi novými vlastnostmi a vlastnostmi, které jsou již známy a jejichž existence již byla v rámci analogie zohledněna. Toto zhodnocení představuje horizontální rozměr jejího modelu analogie. ${ }^{70}$ Podobnost přitom pojímá materiálně, a to jako ,pre-teoretickou analogii mezi pozorovatelnými entitami “. 71

$\mathrm{Z}$ uvedeného pro nás plyne, že nestačí tvrdit pouhou podobnost mezi dvěma (či více) posuzovanými doménami, nýbrž je vhodné vždy identifikovat, ohledně kterých vlastností (vztahů, funkcí) existuje podobnost či dokonce shoda, a u kterých máme co do činění s rozdílností.

Co víc, je třeba určit, které z potencionálně nekonečné řady podobností jsou ty rozhodující pro danou analogickou úvahu, resp. které vlastnosti legitimizují provedení analogického úsudku. Vice versa, je žádoucí vysvětlit, proč ,znaky rozdílné jsou nepodstatné, takže analogické projednání je odiovodněné “. ${ }^{72}$

Zodpovězení těchto otázek nám umožňuje nalézt ten/ty zdroj/e (normativní hypotézu/y či dřívější soudní rozhodnutí), který/é je/jsou vhodným nosičem normativního konsekventu pro námi posuzovaný - cílový př́ípad.

Jak tedy konkrétně postupovat? Kdybychom se drželi strategie navržené M. Hesse, měli bychom v rámci zvažovaných zdrojových př́ípadů zejména kvantitativně poměřovat pozitivní a negativní analogie (tj. zkoumat všechny myslitelné aspekty a faktory, ve kterých se cílová a zdrojová doména shodují/liší). ${ }^{73}$ Odpovídá to tradičnímu pohledu na posouzení relevance závěrů prrijatých cestou analogie. ${ }^{74}$ Nicméně čistě kvantitativní

68 WEINBERGER, c. d., s. 175.

69 KEYNES, J. M. Treatise on Probability. London: Macmillan and Co, 1921, s. 257 et passim.

70 Neméně významný - alespoň z pohledu př́rodních věd - je vertikální rozměr analogie, v rámci kterého je posuzována zejména kauzální souvislost uvnitř určité domény analogie, která však z důvodu výše rozvedených je v oblasti práva méně významná.

71 Toto vymezení otevírá celou řadu otázek, nebot’ není zcela jasné, co se rozumí „ppozorovatelnými entitami“ a co je to „pre-teoretická analogie“, resp. zda toto uchopení není př́iliš zužující. Pokud nejsem s to nějaký objekt pozorovat, znamenalo by to, že nelze ohledně této skutečnosti vyslovit analogii, což je poměrně absurdní závěr. Blíže: NORTON, c. d., s. 10 a násl.

72 WEINBERGER, $c$. d., s. 175.

73 Je třeba upřesnit, že M. Hesse postuluje tyto tři požadavky akceptovatelnosti určitého analogického závěru: (i) podobnost mezi ,pozorovatelnými“ vlastnostmi/znaky cíle a zdroje (viz výše - poznámka pod čarou č. 71); (ii) kauzální vztah mezi přenášenou zdrojovou vlastností a známými pozitivními analogiemi a současně (iii) zdrojová a cílová doména se neliší v žádném podstatném znaku. Blíže: BARTHA, c. d.

74 Mezi tato tradiční vodítka pro posouzení relevance cestou analogie získaných závěrů patří mj. tyto zásady: (i) čím víc podobností, tím je analogie silnější neboli , spolehlivost úsudků z analogie roste s počtem společných znakü“ (ŠTĚPÁN, c. d., s. 60); (ii) čím více rozdílů (tj. negativních) analogií, tím je analogie slabší; (iii) strukturální analogie jsou silnější, než ty opřené na nepřirozených (uměle vytvářených) podob- 
hledisko nelze dle mého soudu přeceňovat, a to mj. vzhledem $\mathrm{k}$ jejich potencionálně neomezenému počtu.

Navíc je nasnadě, že v právní praxi bude poměrně často docházet k případům, kdy v závislosti na procesním postavení daného účastníka řízení budou navrhovány rozdílné zdroje jako ty nejvhodnější (nejpodobnější) k posuzované věci, popř. v rámci nich vyzvedávány rozdílné úhly pohledů. Lze proto přisvědčit názoru J. Whitea, že chápání podobnosti se mnohdy bude odvíjet od toho, ,, kdo a kdy činí rozhodnuti" “. ${ }^{75}$

I kdybychom však zúžili analogie pouze na ty přirozené ( $t j$. nevytvářeli umělá kritéria diferenciace), čistě kvantitativní strategie se nejeví jako optimální. Rozhodující je, zda se srovnávané dílčí (pozitivní či negativní) analogie týkají podstatných (konstitutivních) vlastností/otázek, nebo jsou druhořadé. ${ }^{76}$ Jak totiž připomíná J. Tvrdý, ,, (z) nahodilých podobností vzniká celá řada planých analogií... Vědecký a logický význam mají jen analogie zakládající se na podstatných podobnostech. "77 Také z tohoto důvodu závěr, že ,, analogie smí být použita jen tehdy, pokud je v řešeném případě více shodného, než rozdilů v podobném př́padě, na který analogická norma běžně dopadá “"78 lze považovat za legitimní jen potud, pokud bude doplněn o to, že shoda se má týkat „podstatných náležitostíc6.

Vyvstává takto ale další otázka, jak identifikovat z řady myslitelných faktorů srovnávání dvou domén (tj. kritérií pro dílčí analogii) ty podstatné (konstitutivní)? F. Melzer $\mathrm{v}$ rámci úvah o podstatných a nepodstatných okolnostech př́ípadu zvažovaných $\mathrm{v}$ rámci arg. a simili - navrhuje, aby se pozornost zaměřila na ty aspekty (prvky, vlastnosti, vztahy), které mají význam pro právní posouzení věci. ${ }^{79}$

Konvenuje to s názorem, který propaguje ve svých dílech B. Brożek, a to, aby výběr zdrojů (normativních hypotéz, dříve rozhodnutých př́ipadů) byl určen právní otázkou, kterou v rámci cílového př́ípadu má řešit. Jako podobné mají být proto vybrány všechny ad hoc v úvahu přicházející ,zdroje“, v rámci kterých byl posuzován obdobný právní problém, ${ }^{80}$ či řešen - doplníme-li již na tomto místě o dále podrobněji analyzované Melzerovy úvahy - stejný konflikt zájmů. Namístě již tedy není zkoumání podobností mezi různými myslitelnými doménami, nýbrž v prvé řadě identifikace všech př́ípadů,

nostech; (iv) ,,čím větši bude podobnost struktur obou systémů predevším kvantitativně, tím spolehlivější bude závěr " (tamtéž). K rozboru těchto i dalších kritérií srov. v podrobnostech BARTHA, P. By Parallel Reasoning: the Construction and Evaluation of Analogical Arguments. New York: Oxford University Press, 2010, passim.

75 WHITE, $c . d .$, s. 585.

76 MALINOWSKI, $c . d$., s. 198 a násl.

77 TVRDÝ, c. d., s. 180.

78 HARVÁNEK, J. in: HARVÁNEK, c. d., s. 298.

79 MELZER, c. d., s. 168: „,Je třeba se ptát, zda existuje racionální di̊vod, proč by právě skutečnost, ve které se oba př́pady liší, měla být di̊vodem pro odlišné posouzení věci. " Nutno předznamenat, že Melzerova distinkce je dále spojená s tím, zda daná okolnost může mít vliv na výsledek poměřování principů.

80 BROŻEK, Analogy in Legal Discourse, s. 195 a násl.; BROŻEK, Is Analogy a form of legal reasoning?, s. 59 a násl.; či třeba BROŻEK, B. Myślenie: podręcznik użytkownika. Kraków: Copernicus Center Press, 2019, s. 222 a násl. 
$\mathrm{v}$ rámci kterých je/byl řešen tentýž problém/konflikt zájmů jako $\mathrm{v}$ aktuálně projednávané věci. ${ }^{81}$ Odhaluje se v této souvislosti i kontextuální charakter analogie. ${ }^{82}$

Tento př́ístup umožňuje efektivně eliminovat ,zdánlivé“ či „účelově navrhované“ zdrojové normativní hypotézy či dřívější rozhodnutí soudu, a potažmo tedy najít zdroje jen, „životaschopných“ analogií.

Lze přitom dodat, že $\mathrm{v}$ právní praxi právníci obvykle intuitivně volí tuto strategii a jsou schopni též bez větších obtíží odlišit podstatné od nepodstatných okolností/náležitostí př́ípadu. ${ }^{83}$ Nicméně z požadavku logické formy analogie, jež je předpokladem její legitimizace (viz výše), pramení potřeba racionalizovat a v odůvodnění rozhodnutí zaznamenat tyto procesy. ${ }^{84}$

Ačkoliv popsaný návrh Melzera i Brożka vykazuje značnou podobnost, lze si povšimnout, že Brożkovo řešení dává návod, jak identifikovat všechny potencionální zdroje analogie, kdežto Melzer se spíše věnuje otázce posouzení okolností v rámci určitého již relevantně-podobného př́padu. ${ }^{85}$ Vzhledem k požadavku explicitního vyjádření všech premis stojících za analogickým úsudkem se tak jeví jako vhodnější postup navržený B. Brożkem. Ba, co víc, ukazuje, že jednou z vůbec prvních otázek, kterou by měl orgán aplikující právo vždy řešit, je zjištění právního problému a identifikace okruhu možných zdrojů, ve kterých lze nalézt normativní řešení (zejména tedy vyhledání vhodných ustanovení, popř. určení právního odvětví či jeho výseče, který daný rod problémů řeší ${ }^{86}$ ). Není-li přitom nalezena aplikovatelná zákonná právní norma, je namístě posouzení tzv. analogické situace $\mathrm{u}$ identifikovaných zdrojů analogie (tj. je třeba vyhodnotit povahu mezery $\mathrm{v}$ zákoně, zkoumat př́pustnost analogie $\mathrm{v}$ daném právním

81 „Je to otázka, kterou chceme zodpovédět, jež vyznačuje podobnosti prima facie mezi dvěma připady - budeme zohledňovat ty minulé situace, ve kterých jsme řešili podobný př́pad jako je ten aktuálně posuzovaný“ (BROŻEK, Myślenie: podręcznik użytkownika, s. 223).

82 Blíže: WOJTCZAK, $c$. d., s. 118 a násl. Od řešené otázky se tedy bude odvíjet identifikace klíčových aspektů dané věci. V závislosti na řešeném právním problému, tj. zda ad hoc budeme posuzovat civilněprávní odpovědností vztah či třeba trestněprávní rovinu, budeme do popředí vyzvedávat rozdílné fakty, vlastnosti či vztahy, ačkoliv stále budeme mít co do činění s týmž případem.

83 Jde o rychlá, automatizovaná rozhodnutí, jež od nás nevyžadují větší námahu a jež jsou realizována v rámci tzv. Systému 1 (tj. souboru dovedností, které nám dílem byly dány do vínku, dílem se jedná o automatizované mentální aktivity, které vyvěrají z našich předchozích zkušeností a znalostí). Obvykle teprve, ,, $k d y z ̌$ se Systém 1 dostane do potiží, zavolá si na pomoc Systém 2, aby přispěl s podrobnějším a konkrétnějším zpracováním “(KAHNEMAN, D. Myšlení rychlé a pomalé. Příbram: Melvil Publishing, 2011, s. 31). Jak upřesňuje B. Brożek, ,, analogické usuzování je zakořeněno v lidské schopnosti mentálního simulování dějů. ... kdy využiváme minulé prípady, ve kterých se podařilo vyřešit určité otázky, a to pro daný prípad... Využiváme pritom metodu variace" (BROŻEK, B. Umyst prawniczy. Kraków: Copernicus Center Press, 2019, s. 109).

84 V právu je tedy nezbytné, aby analogické rozhodnutí mělo oporu - budeme-li se držet terminologie D. Kahnemana - i v Systému 2 a bylo plodem racionální, v odůvodnění daného rozhodnutí zaznamenané úvahy soudu.

85 Nalezení relevantně podobného př́padu představuje až druhý krok v rámci Brożkova modelu analogie. F. Melzer tak pracuje s jednostupňovým modelem, kdy za vhodný zdroj pro analogii považuje jen ta ustanovení, která řeší stejný konflikt zájmů (MELZER, c. d., s. 168), resp. mají ,, alespoň v podstatných bodech stejný ... teleologický základ" (s. 245). Podstatné okolnosti/body případu pak jsou způsobilé ovlivnit řešení tohoto konfliktu.

86 V závislosti na řešených otázkách lze identifikovat jako prima facie podobné zdroje i ustanovení upravená v různých právních předpisech či odvětvích, a to pokud řeší ,stejný konflikt zájmư“, s jakým ad hoc máme co do činění. Blíže: MELZER, c. d., s. 168. 
odvětví apod.). Teprve poté bude namístě přistoupit k řešení otázky podobnosti podstatných náležitostí zdroje a cíle analogie.

Ani na této úrovni však nestačí kvantitativně a víceméně automatizovaně srovnat pozitivní a negativní analogie ohledně podstatných náležitostí, a budou-li převládat ty pozitivní, použít zákonný konsekvent zdroje na cílový př́ípad. „,[P]ravděpodobnost úsudku analogického není pravděpodobností početní (numerickou), ... nýbrž pravděpodobností, kterou rozmanitě nazývají logickou, filozofickou, racionální a která má svůj původ v zákonitosti jevů. Vlastnosti, jejichž společnou existenci na základě analogie vyvozujeme, nevyskytuji se společně nahodile, nýbrž tvoři určitou zákonitou souvislost. "87 Převedeno do oblasti práva, je tedy třeba zkoumat, co vlastně stojí za daným normativním ustanovením, jaké je jeho ratio legis, a zda je vskutku legitimní tento sekundární zdroj vztáhnout i na posuzovaný cílový př́pad. Budeme tedy - v souladu s modálním postojem - testovat prima facie analogií získané závěry.

\section{K TELEOLOGICKÉ PODOBNOSTI ANEB K LEGITIMIZACI NORMATIVNÍHO KONSEKVENTU}

Tak jako v př́ípadě právního ustanovení nelze pro účely jeho aplikace bez dalšího vycházet z čistě jazykového znění, tak i v situaci, kdy nalezneme př́ípad (normativní ustanovení či předchozí rozhodnutí), který řeší prima facie stejnou právní otázku, není namístě bez dalšího aplikovat příslušný normativní konsekvent. Je tedy třeba zkoumat, jaký účel, hodnoty a principy stojí v pozadí zvažovaného zdroje normativní úpravy. K tomuto postupu v oblasti občanského práva vybízí i samotný normotvưrce, a to když ukládá, aby bylo dotvořeno právo ,podle ustanovení, které se týká právního př́padu co do obsahu a účelu posuzovanému právnímu př́padu nejbližšiho " (\$ 10 odst. 1 obč. zákoníku). ${ }^{88}$

Tento postup bude o to významnější, pokud v rámci hledání prima facie podobných př́padů nalezneme více potencionálních zdrojů normativních konsekventů (vícero zákonných ustavení či právních případů), jež nabízejí rozdílná řešení. ${ }^{89}$

I kdybychom však nalezli jeden zdrojový př́pad, je namístě zkoumat, zda bychom aplikací zákonného normativního konsekventu nezískali hodnotově nekonzistentní rozhodnutí, jež by narušovalo hodnotovou koherenci právního řádu (či jeho výseče).

Jak postupovat $\mathrm{v}$ rámci řešení těchto otázek a zejména, jak racionalizovat provedené volby? Co se týče prvního z naznačených problémů - provedení volby mezi více po-

87 TVRDÝ, c. d., s. 121.

88 Lze v tomto kontextu poukázat i na zásadu: Ubi eadem legis ratio, ibi eadem legis dispositio, tj. kde lze spatřovat stejný motiv, je namístě obdobná úprava práv a povinností.

89 V právní doktríně se můžeme přitom setkat s názory, že v případě výskytu proti-plánové mezery v zákoně, kterou lze vyplnit cestou analogie, převládají obvykle situace, kdy máme k dispozici více možných zdrojů analogie. (BROŻEK, Is analogy a form of legal reasoning?, s. 59). Jako stěžejní se pak jeví výběr tohoto nejrelevantnějšího případu, k němuž dochází právě v rámci hledání relevantní (teleologické) podobnosti. Tento pohled se ale zdá, že více reflektuje anglosaskou aplikační praxi. V kontinentálním právu, a to mj. vzhledem k přednosti analogie legis před analogii iuris (viz výše), je třeba primárně vycházet ze zdrojů obsažených v normativních právních textech, teprve není-li jich, popř. vedou-li k protisystémovým závěrům, zohledňovat i další - sekundární - zdroje. 
tencionálními zdroji, pomocný mechanismus může nabídnout zpochybnitelná logika (defeasible logic) rozvinutá zejména H. Prakkenem a G. Sartorem, ${ }^{90}$ jež doporučuje na základě dostupných premis formulovat dílčí argumenty, a to i protichůdné (první stupeň), které posléze jsou srovnávány a vyhodnocovány, a to za účelem výběru finálního řešení. V námi rozvažovaném kontextu je tedy namístě formulace všech myslitelných pracovních analogických pravidel (vyvozených z prima facie podobných zdrojů), jež jsou posléze srovnávány. Budou-li nalezeny rozdíly mezi dílčími závěry, je třeba vybrat ten ze závěrů, který se opírá o pádnější zpochybnitelnou implikaci. ${ }^{91} \mathrm{O}$ tom, která ze zpochybnitelných analogických implikací (argumentací) je pádnější, lze pak rozhodnout na základě postupů, jež jsou v dané interpretační komunitě preferovány. Může tedy přícházet v úvahu využití Alexyho vážící formule, ${ }^{92}$ jež nám umožní na základě poměřování principů, jež stojí v pozadí zvažovaných závěrů, vybrat ten významnější, potažmo tedy i relevantnější zdroj. ${ }^{93}$ Nicméně mohou to být i jiná přijímaná kritéria, např. ta, jež byla rozvinuta představiteli Law and Economics. Co je zásadní, orgán veřejné moci by měl v odůvodnění svého rozhodnutí vysvětlit, proč byl zvolen právě tento normativní konsekvent. ${ }^{94}$

Rovněž v případech, kdy máme co do činění s jediným potencionálním možným zdrojem normativního konsekventu, je namístě zkoumání hodnot, stojících v pozadí úpravy, a to aby se zamezilo - př́ípadným rozšířením zákonného antecedentu i na cílový př́ípad - nekonzistentní aplikaci práva, narušující jeho vnitřní systém. ${ }^{95} \mathrm{I} v$ tomto prŕpadě je tedy namístě zdůvodnění postupu dle analogie legis, anebo vysvětlení, proč je vhodnější dotvořit právo jiným způsobem.

Závěrem je třeba poznamenat, že v rámci výkladu zdrojového normativního konsekventu je třeba vždy zohlednit i aktuální interpretační diskurz, co se týče zdrojové-

90 Blíže: PRAKKEN, H. Logical Tools for Modelling Legal Argument: a Study of Defeasible Reasoning in Law. Dordrecht: Kluwer Academic Publishers, 1997; PRAKKEN, H. - SARTOR, G. The Three Faces of Defeasibility in Law. Ratio Juris. 2004, No. 17, s. 118-139. V češtině ke zpochybnitelné logice vč. kritických připomínek srov. HOLLÄNDER, P. Nový logicismus v teoretickém právním myšlení. In: České právní myšleni a logika - minulost a perspektivy: sborník př́spěvků z konference. Brno: Masarykova univerzita v Brně, 2003, s. 87-97; popř. recentně ŽÁK KRZYŽANKOVÁ, K. Právní interpretace-mezi vysvétlováním a rozuméním. Praha: Wolters Kluwer ČR, 2019, s. 134 a násl.

91 Oproti klasické logice je jazyk zpochybnitelné logiky obohacen o tzv. zpochybnitelnou implikaci, která je využívána k označení inferencí uvnitř zpochybnitelných argumentů, tj. uvnitř argumentů, jejichž platnost se může změnit (nap̌r. dodáním nové premisy, anebo silnějším argumentem).

92 Srov. ALEXY, R. Lidská důstojnost a princip proporcionality. Právník. 2015, č. 11, s. 867-878, popř. též vč. kritických poznámek WINTR, J. Alexyho vážící formule. Právník. 2016, č. 5, s. 446 a násl., nebo ONDŘEJEK, P. Poměřování jako klíčový argument přezkumu ústavnosti v éře proporcionality a některé projevy jeho kritiky. Právník. 2016, č. 4, s. 349-368.

93 Tento postup preferuje zde opakovaně připomínaný B. Brożek. Poměřování principů tak v jeho koncepci tvoří nedílnou součást analogie. Sám přitom hovoří o „,tezi částečné redukce“ (Partial Reducibility Thesis) analogie v poměřování. (Srov. BROŻEK, Analogy in Legal Discourse, s. 197). V pozdějších pracích, byt’ ne zcela důsledně, ale začíná připouštět i využití jiných kritérií. Lze dodat, že samotný R. Alexy považuje analogii za samostatnou a základní operaci - vedle subsumpce a poměřování - využitelnou v rámci aplikačních procesů, a tedy jeho názory nekonvenují s Brożkovými rozvinutími jeho koncepce. Blíže: ALEXY, R. Two or Three? In: BOROWSKI, M. (ed.). On the Nature of Legal Principles. ARSP-Beiheft 119, Stuttgart: Franz Steiner, s. 9-18.

94 Je tedy třeba uvést ospravedlnění této podoby analogie. Odpovídá to Brewerovu požadavku uvést v rámci logické formy tzv. analogy-warranting rationale (BREWER, Indefeasible analogical argument, s. 44).

$95 \mathrm{~K}$ vnitřní struktuře práva srov. v tuzemské literatuře ONDŘEJEK, P. Koncepce práva jako systému. Praha: Wolters Kluwer ČR, 2020, s. 172 a násl. 
ho ustanovení, a to cestou analýzy judikatury zejména vyšších soudů. Umožní nám to jednak lépe identifikovat principy a hodnoty stojící v pozadí dané úpravy, jednak vhodně - v souladu s ustálenou praxí - aplikovat relevantní právní konsekvent, popř. vysvětlit, proč nebyl ustáleným způsobem aplikován. Legitimní důvod této odchylky přitom může spočívat $\mathrm{v}$ potřebě uzpůsobit zákonný normativní konsekvent, resp. jeho ustálený výklad, specifickým potřebám dané situace. ${ }^{96}$

Zvláštní pozornost by pak měla být věnována i rozhodnutím, ve kterých soudy v minulosti dotvořily zákonný normativní konsekvent pro obdobný př́ípad jako je ten aktuálně řešený. Lze si přitom všimnout, že postupně může vznikat - byt' na úrovni judikatury - nové pravidlo, které oproti dotváŕenému zákonnému ustanovení má již širší antecedent, ${ }^{97}$ popř. i dílem modifikovaný konsekvent, a to např́iklad ohledně určité povinnosti či práva.

\section{ZÁVĚREM}

Představené úvahy můžeme shrnout do následujících bodů, jež můžou přispět k lepší strukturaci úvah i vlastní argumentace při dotváření práva cestou analogie, a potažmo takto i zvýšit přesvědčivost daného rozhodnutí a obecnou pro-systémovost nalézání práva ze strany orgánů veřejné moci.

Konkrétně lze doporučit tento postup:

1. seznámení se s cílovou doménou analogie a formulace právní otázky, která má být řešena;

2. identifikace zdroje či zdrojů analogie, tj. zákonných ustanovení, a není-li jich, zásad stojících za danou výsečí práva, popř. dalších - sekundárních - zdrojü, které řeší daný právní problém či rod problémů, ev. obdobný konflikt zájmů (tj. vyhledání prima facie podobných zdrojů analogie);

3. vyhodnocení otázky príípustnosti analogie a zkoumání povahy mezer v zákoně (ve vztahu k prima facie podobným zdrojům; ev. zvážení postupu dle arg. a contrario);

4. máme-li co do činění s analogickou situací (prošli jsme bodem 3), tak dochází k:

a) k porovnání dílčích pozitivních a negativních analogií mezi cílem a prima facie zdrojovými př́pady ohledně podstatných okolností případu (tj. zkoumání míry faktické podobnosti, existuje-li tedy podobné/á ustanovení v zákoně); a současně

b) zkoumání míry „teleologické“ podobnosti a konzistence (formulace dílčích zpochybnitelných argumentů, a to na základě zvažovaných zdrojových normativních konsekventů; eliminace variant narušujících vnitřní koherenci práva; výběr - ze zbývajících - varianty, jež se opírá o nejpádnější zpochybnitelnou implikaci jako kritérium lze použít poměřování principů apod.);

5. je-li shledána faktická i teleologická podobnost - postup per analogiam legis; tj. stanovení obsahu dotvořeného práva (a to po zohlednění judikatury a specifik dané věci);

96 MORAWSKI, c. d., s. 231.

97 Antecedent bude tvořit množina př́padů, pro které bylo zákonné pravidlo cestou analogie použito. 
6. nelze-li postupovat per analogiam legis (není-li shledána faktická podobnost, poprr. nenalezeno žádné normativní ustanovení, jež by řešilo danou právní otázku), postup per analogiam iuris - lze vyjít $\mathrm{z}$ výsledku poměřování sub $4 \mathrm{~b}$, a to po zohlednění dalších kritérií (doktrína, judikatura apod.);

7. odůvodnění analogického úsudku, zejména výběru premis a provedených voleb (zejména provedených $\mathrm{v}$ bodě 4 , např. jelikož cílový případ sdílí s jediným identifikovaným zdrojovým př́padem tyto faktické pozitivní analogie $\mathrm{x}, \mathrm{y}, \mathrm{z}$, přičemž pro zdrojový případ je př́iznačný normativní konsekvent $\mathrm{L}$, který nenarušuje vnitřní koherenci právního řádu, a shledaná negativní analogie je nevýznamná, na cílový postup byl aplikován normativní konsekvent L).

K uvedenému je ale třeba poznamenat, že představené dílčí kroky nejsou navzájem striktně odlišeny. Nelze též odmítat či neupřednostnit jiný postup, bude-li vyjevena jeho logická forma, nebot' tč. neexistuje jediné správné a možné schéma analogického úsudku. Je konečně nasnadě, že pokud ve vztahu k určitému právnímu problému již bylo právo cestou analogie dotvořeno a $\mathrm{v}$ aktuálně projednávaném př́padě nebyly nalezeny žádné podstatné rozdíly, není třeba odůvodnění logické formy již věnovat takovou pozornost, jakou by vyžadoval př́pad doposud v praxi neřešený.

JUDr. Katarzyna Žák Krzyžanková, Ph.D.

Právnická fakulta Univerzity Karlovy

krzyzank@prf.cuni.cz 